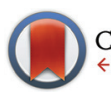

CrossMark click for updates

Cite this: Org. Biomol. Chem., 2015, 13, 4706

Received 12th February 2015,

Accepted 9th March 2015

DOI: 10.1039/c5ob00301f

www.rsc.org/obc

\section{Investigations of possible prodrug structures for 2-(2-mercaptophenyl)tetrahydropyrimidines: reductive conversion from anti-HIV agents with pyrimidobenzothiazine and isothiazolopyrimidine scaffolds $\uparrow$}

\author{
Shiho Okazaki, ${ }^{a}$ Shinya Oishi, ${ }^{a}{ }^{a}$ Tsukasa Mizuhara, ${ }^{a}$ Kazuya Shimura, ${ }^{b}$

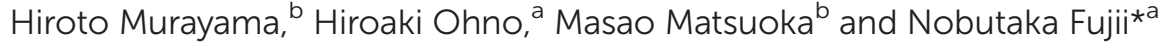

3,4-Dihydro-2H,6H-pyrimido[1,2-c][1,3]benzothiazin-6-imine (PD 404182) and 3,4-dihydro-2H-benzo$[4,5]$ isothiazolo[2,3-a]pyrimidine are the heterocyclic antiretroviral agents against human immunodeficiency virus type 1 (HIV-1) infection. On the basis of similar structure-activity relationships of anti-HIV activities toward the early-stage of viral infection between these unique scaffolds, the transformations under the bioassay conditions were investigated. The distinctive $\mathrm{S}-\mathrm{N}$ bond in the isothiazolopyrimidine scaffold was immediately cleaved under reductive conditions in the presence of GSH to generate a thiophenol derivative. A similar rapid conversion of PD 404182 into the same thiophenol derivative was observed, suggesting that pyrimidobenzothiazine and isothiazolopyrimidine scaffolds may work as prodrug forms of the common bioactive thiophenol derivatives.

\section{Introduction}

PD 404182 (1a, 3,4-dihydro-2H,6H-pyrimido[1,2-c][1,3]benzothiazin-6-imine $)^{1-4}$ is an antiviral agent against human hepatitis C virus (HCV) ${ }^{5,6} \mathrm{HIV},{ }^{6-10}$ simian immunodeficiency virus (SIV), ${ }^{6}$ and herpes simplex virus (HSV) (Fig. 1). ${ }^{10}$ 3,4-Dihydro$2 H$-benzo[4,5]isothiazolo[2,3-a]pyrimidine 2a with a unique heterocyclic scaffold also exhibits potent anti-HIV activity $\left(\mathrm{EC}_{50}=0.29 \pm 0.09 \mu \mathrm{M}\right)$ (Fig. 1). ${ }^{11}$ In our recent studies, we

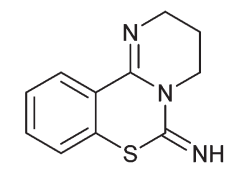

1a (PD 404182)

$\left[\mathrm{EC}_{50}=0.30 \pm 0.06 \mu \mathrm{M}\right.$ ]

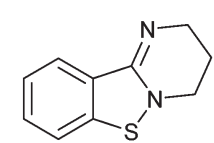

$2 a$

$\left[E C_{50}=0.29 \pm 0.09 \mu \mathrm{M}\right]$
Fig. 1 Structures of PD 404182 (1a) and benzo[4,5]isothiazolo[2,3-a]pyrimidine (2a).

${ }^{a}$ Graduate School of Pharmaceutical Sciences, Kyoto University, Sakyo-ku, Kyoto 606-8501, Japan.E-mail:soishi@pharm.kyoto-u.ac.jp,nfujii@pharm.kyoto-u.ac.jp; Fax: +81-75-753-4570; Tel: +81-75-753-4561

${ }^{b}$ Institute for Virus Research, Kyoto University, Sakyo-ku, Kyoto, 606-8507, Japan $\dagger$ Electronic supplementary information (ESI) available. CCDC 1037500. For ESI and crystallographic data in CIF or other electronic format see DOI: 10.1039/ c5ob00301f revealed that modification of the 9-position of PD 404182 derivatives with hydrophobic aryl groups improved the anti-HIV activity. ${ }^{7-9}$ For example, the introduction of an aryl $(\mathbf{1 b}, \mathbf{1} \mathbf{c}$ and 1f) or bromo (1d) substituent at the 9-position led to a two- to three-fold increase in the anti-HIV activity compared with compound 1a (Table 1). This improvement was duplicated by the modification of benzo[4,5]isothiazolo[2,3- $a]$ pyrimidine derivatives at the 8-position ( $\mathbf{2 b}, \mathbf{2} \mathbf{c}, \mathbf{2 d}$ and $\mathbf{2 f}$ ), which is the equivalent position of the 9-position in pyrimido[1,2-c][1,3]benzothiazin-6-imine. Similarly, introduction of acetamido group at the equivalent positions resulted in a complete loss of the anti-HIV activity of both the PD 404182 derivative (1e) and isothiazolopyrimidine derivative (2e). Furthermore, a complete loss of anti-HIV activity was observed by the introduction of the 8-bromo and 7-bromo groups to the parent compounds (19 and $\mathbf{2 g}$, respectively). These similar structure-activity relationships implied that the same target molecule(s) or mechanism(s) of action could possibly be involved in the antiHIV activities of PD 404182 and the isothiazolopyrimidine derivatives.

In addition, heterocyclic compounds 1a and 2a both inhibited early-stage HIV infection including virus attachment and membrane fusion to host cells as exemplified in comparison with DS 5000 (adsorption inhibitor) $^{12}$ and enfuvirtide (fusion inhibitor) ${ }^{13}$ Although it was suggested that the antiviral effects of compound 1a are derived from its virucidal effect against viral particles, ${ }^{14}$ its antiviral mechanism of action has not yet 
Table 1 Comparison of the structure-activity relationships of PD 404182 derivatives and benzo[4,5]isothiazolo[2,3-a]pyrimidines

Id

\footnotetext{
${ }^{a} \mathrm{EC}_{50}$ values represent the concentration of the compound required to inhibit the HIV-1 infection by $50 \%$. The data were obtained from three independent experiments by the MAGI assay. ${ }^{b} \mathrm{EC}_{50}$ values were obtained by the NCK assay. ${ }^{c} \mathrm{EC}_{50}$ values were obtained by the NCK assay, compound 1a: $0.30 \pm 0.06 \mu \mathrm{M}$; compound 1d: $0.14 \pm 0.02 \mu \mathrm{M}$; compound 1g: $>10 \mu \mathrm{M}$. ${ }^{d}$ Cytotoxicity was observed at $10 \mu \mathrm{M}$.
}

been sufficiently detailed. In the current study, we investigated the chemical transformations of pyrimido[1,2-c][1,3]benzothiazin-6-imine derivatives 1 and benzo[4,5]isothiazolo[2,3-a]pyrimidine derivatives 2 under the bioassay conditions.

\section{Results and discussion}

\section{Synthesis}

PD 404182 derivatives 1 and benzo[4,5]isothiazolo[2,3-a]pyrimidine derivatives 2 were synthesized according to the protocols in our previous studies (Scheme 1). ${ }^{7,8,11} 2$-(2-Mercaptophenyl)tetrahydropyrimidine derivatives $\mathbf{4}$ were obtained by trifluoroacetic acid (TFA)-mediated ethanolysis of the imino group in pyrimido[1,2-c][1,3]benzothiazin-6-imines 1 . The alternative route via alkaline hydrolysis of pyrimido[1,2-c][1,3]benzothiazin-6-thione 3 also generated thiophenol derivatives 4. Some thiophenol derivatives 4 could be isolated as stable crystals, such as 2-(2-mercaptophenyl)-, 2-(4-bromo-2-mercaptophenyl)- or 2-(3-bromo-2-mercaptophenyl)-tetrahydropyrimidine $(\mathbf{4 a}, \mathbf{d}, \mathbf{g})$. Thioanisole derivative 7 was obtained by the oxidative amidination of the corresponding benzaldehyde $5 .{ }^{15,16}$ Sulfuric acid-mediated deprotection of $N$-tosylated tetrahydropyrimidine 8, derived from benzaldehyde 6 by the identical protocol, ${ }^{7}$ afforded aniline derivative $\mathbf{9}$.

\section{Identification of the inactive ingredient by transformation from PD 404182 in aqueous media}

Recently, Chamoun-Emanuelli et al. reported that the antiviral activity of PD 404182 (1a) disappeared during storage under some conditions (for example, in Dulbecco's phosphatebuffered saline ( $\mathrm{pH} 7$ ) at $\left.42{ }^{\circ} \mathrm{C}\right) .{ }^{10}$ During our studies on PD<smiles></smiles>

1

a<smiles>Sc1ccccc1C1=NCCCN1</smiles>

4<smiles>[R]c1ccccc1C=O</smiles>

$\mathrm{R}^{\prime}=\mathrm{SMe}(\mathbf{5})$

$\mathrm{R}^{\prime}=\mathrm{NHTS}(6)$<smiles>S=C1Sc2ccccc2C2=NCCCN12</smiles>

3

$\mathrm{b}$

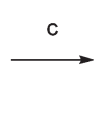<smiles>c1ccc2c(c1)SN1CCCN=C21</smiles>

2

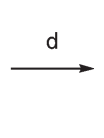<smiles>[R]c1ccccc1C1=NCCCN1</smiles>

$\mathrm{R}^{\prime}=\mathrm{SMe}(7)$

$e \longrightarrow R^{\prime}=N_{T T s}(8)$
$\mathrm{R}^{\prime}=\mathrm{NH}_{2}(9)$
Scheme 1 Synthesis of benzo[4,5]isothiazolo[2,3-a]pyrimidine and 2-phenyl-1,4,5,6-tetrahydropyrimidine derivatives. Reagents and conditions: (a) TFA, $\mathrm{CHCl}_{3}-\mathrm{EtOH}$ or EtOH, rt; (b) $\mathrm{NaOH}, \mathrm{MeOH}-\mathrm{H}_{2} \mathrm{O}$, reflux; (c) PIDA, $\mathrm{CHCl}_{3}$ and/or EtOH, rt; (d) 1,3-propanediamine, $\mathrm{I}_{2}, \mathrm{~K}_{2} \mathrm{CO}_{3}$, $t$ - $\mathrm{BuOH}, 70{ }^{\circ} \mathrm{C}$; (e) conc. $\mathrm{H}_{2} \mathrm{SO}_{4}, 100{ }^{\circ} \mathrm{C}$.

404182 derivatives, we also found that the anti-HIV activity from the stock solution of 1a in DMSO was often attenuated. X-ray crystallography of the predominant component from 1a revealed that the resulting product was 3,4-dihydro- $2 \mathrm{H}, 6 \mathrm{H}^{-}$ 


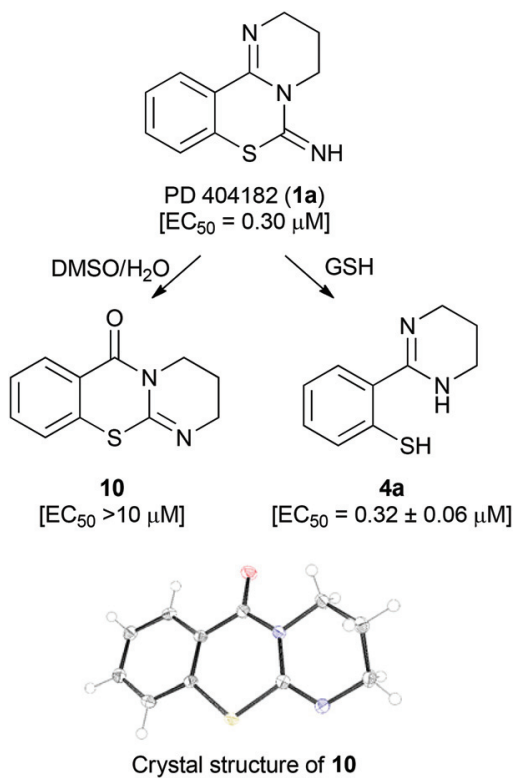

Fig. 2 Transformations of PD 404182 under assay conditions and under reductive conditions in the presence of $\mathrm{GSH}$ at $37^{\circ} \mathrm{C}$. $\mathrm{EC}_{50}$ values represent the concentration of the compound required to inhibit the HIV-1 infection by $50 \%$. The data were obtained from three independent experiments by the NCK assay.

benzo[e $]$ pyrimido[2,1- $b][1,3]$ thiazin-6-one 10 (Fig. 2). An apparent rearrangement of the cyclic amidine substructure in 1a provided pyrimidothiazinone $\mathbf{1 0}$ with no anti-HIV activity. In contrast, benzo[4,5]isothiazolo[2,3- $a]$ pyrimidine 2a was stable in acidic and basic solutions, and the assay medium containing fetal calf serum.

Transformation of PD 404182 and benzo[4,5]isothiazolo[2,3-a]pyrimidine derivatives under reductive conditions in the presence of GSH

We investigated the conversion of PD 404182 (1a) in the presence of high glutathione (GSH) concentrations that mimic the intracellular environment. ${ }^{17}$ Interestingly, the imino group of 1a decomposed in $10 \mathrm{mM}$ GSH solution at $37^{\circ} \mathrm{C}$, and was converted into thiophenol 4a within $1 \mathrm{~h}$ (Fig. 2 and 3). ${ }^{18}$ This thiophenol derivative $\mathbf{4 a}$ exhibited equipotent anti-HIV activity as the parent compound $1 \mathrm{a}\left(\mathrm{EC}_{50}=0.32 \pm 0.06 \mu \mathrm{M}\right)$. The mechanism of conversion from 1a into thiophenol 4 a could be via the release of cyanylated glutathione, which was detected by ESI-MS analysis. ${ }^{19}$

Our previous structure-activity relationship study of $\mathbf{1 a}$ demonstrated that the 6-imino group and the 7-sulfur atom in 1a were indispensable for the anti-HIV activity (Table 2). ${ }^{7}$ For example, substitution of the imino group in compound 1a with a carbonyl (13) or thiocarbonyl (3a) group resulted in a significant decrease or loss of activity. Neither pyrimido[1,2-c]$[1,3]$ benzoxazines $(\mathbf{1 4 a}-\mathbf{c})$ nor pyrimido[1,2-c]quinazolines (15a-c) exhibited anti-HIV activity (Table 2). In the presence of GSH, the carbonyl (13) and thiocarbonyl (3a) derivatives were slowly converted to compound $\mathbf{4 a}$ in 26 and $15 \%$ yield, respectively, after $24 \mathrm{~h}$ (Table 2, Fig. 3). This is in contrast with the rapid and quantitative conversion from 1a within $1 \mathrm{~h}$, indicating that a more reactive imino group in $\mathbf{1 a}$ was a prerequisite for the efficient generation of $\mathbf{4 a}$ with potent anti-HIV activity. In the absence of GSH, compound $\mathbf{1 3}$ was converted into $\mathbf{4 a}$ in only $5 \%$ yield for $24 \mathrm{~h}$, and $3 \mathrm{a}$ did not produce $\mathbf{4 a}$, indicating that degradation of $\mathbf{1 3}$ and $\mathbf{3 a}$ was mainly mediated by $\mathrm{GSH}^{20}{ }^{20}$ Compound $\mathbf{1 4 a}$ was unstable in the presence or absence of GSH to give a cyclic carbamate $14 \mathrm{~b}$ and a phenol derivative $16,{ }^{7,21}$ which showed no antiHIV activity. The carbamate $\mathbf{1 4 b}$ and thiocarbamate $14 \mathbf{c}$ were also degraded into an inactive phenol 16 in 78 and 71\% yield, respectively, in GSH solution over $24 \mathrm{~h}$. The pyrimido$[1,2-c]$ quinazolines $(\mathbf{1 5 a}-\mathbf{c})$ were stable under identical conditions, and thus, did not produce the possible aniline $\mathbf{9}$. In light of these results, the absent or diminished antiHIV activity of $\mathbf{3 a}$ and $\mathbf{1 3 - \mathbf { 1 5 }}$ is likely attributable to decreased conversion to the potent thiophenol $4 \mathbf{a}$ or the poor antiHIV activity of the parent compounds and ring-opened products.
(A)

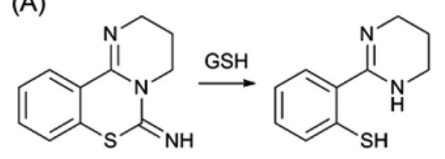

1a (PD 404182)

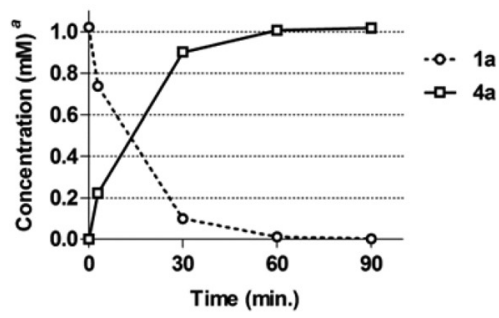

(B)

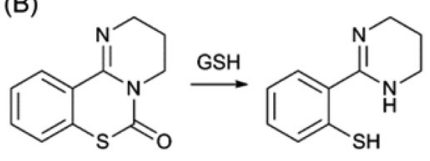

$4 a$

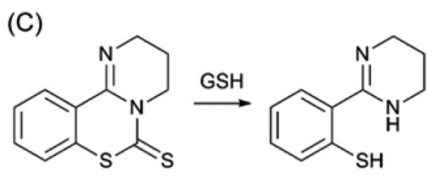

$3 a$

$4 a$

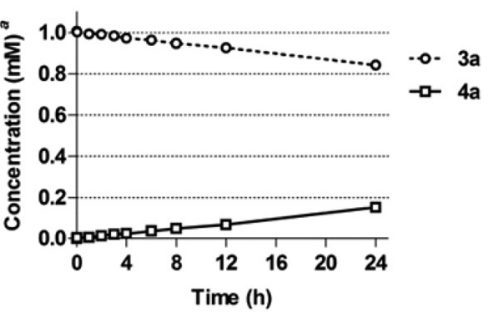

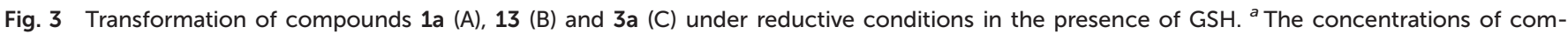
pounds were calculated by HPLC analysis using previously determined calibration curves. 
Table 2 Reactions of PD 404182 derivatives under reductive conditions in the presence of GSH<smiles>[X]C1=[SH]c2ccccc2C2=NCCCN21</smiles><smiles></smiles>

1a, 13, 3a<smiles></smiles>

14a-c<smiles>[X]C1=Nc2ccccc2C2=NCCCN12</smiles>

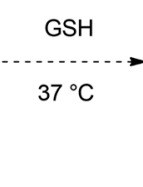

$9\left[\mathrm{EC}_{50}>10 \mu \mathrm{M}\right]^{a}$

\begin{tabular}{llll}
\hline Cmpd & $\mathrm{X}$ & $\mathrm{EC}_{50}{ }^{b, 7}(\mu \mathrm{M})$ & Conversion (time, yield $\left.{ }^{c}\right)$ \\
\hline PD 404182 (1a) & $\mathrm{NH}$ & $0.44 \pm 0.08$ & $\mathbf{4 a}(1 \mathrm{~h}$, quant.) \\
$\mathbf{1 3}$ & $\mathrm{O}$ & $8.94 \pm 1.07$ & $\mathbf{4 a}(24 \mathrm{~h}, 26 \%)^{d}$ \\
$\mathbf{3 a}$ & $\mathrm{S}$ & $>10$ & $\mathbf{4 a}(24 \mathrm{~h}, \mathbf{1 5 \%})^{d}$ \\
$\mathbf{1 4 a}$ & $\mathrm{NH}$ & $>10$ & $\mathbf{1 6}+\mathbf{1 4 b} \mathbf{b}^{e}$ \\
$\mathbf{1 4 b}$ & $\mathrm{O}$ & $>10$ & $\mathbf{1 6}(\mathbf{2 4} \mathrm{h}, 78 \%)$ \\
$\mathbf{1 4 c}$ & $\mathrm{S}$ & $>10$ & $\mathbf{1 6}(24 \mathrm{~h}, 71 \%)$ \\
$\mathbf{1 5 a}$ & $\mathrm{NH}$ & $>10$ & No reaction \\
$\mathbf{1 5 b}$ & $\mathrm{O}$ & $>10$ & No reaction \\
$\mathbf{1 5 c}$ & $\mathrm{S}$ & $>10$ & No reaction
\end{tabular}

${ }^{a} \mathrm{EC}_{50}$ values represent the concentration of the compound required to inhibit the HIV-1 infection by $50 \%$. The data were obtained from three independent experiments by the NCK assay. ${ }^{b} \mathrm{EC}_{50}$ values were obtained by the MAGI assay. ${ }^{c}$ The product yields were calculated by HPLC analysis using previously determined calibration curves. ${ }^{d}$ The reactions were also carried out in the absence of GSH: $5 \%$ conversion from 13 after $24 \mathrm{~h}$; no reaction from $3 \mathrm{a}$. ${ }^{e}$ The accurate product yields of $14 \mathrm{~b}$ and 16 by GSH-mediated conversion were not calculated because of the chemical instability of the substrate 14a.

We next focused on the isothiazolopyrimidine scaffold of 2 a with a characteristic S-N covalent bond, which is contained in several anti-HIV agents against HIV-1 nucleocapsid protein 7 (NCp7). ${ }^{22-24}$ We assessed the stability of compound $2 \mathbf{a}$ under identical GSH-containing conditions (Fig. 4). In $10 \mathrm{mM} \mathrm{GSH}$ solution at $37{ }^{\circ} \mathrm{C}$, compound $\mathbf{2 a}$ was also immediately converted to a thiophenol derivative $4 \mathrm{a}$ with potent anti-HIV activity $(<3 \mathrm{~min})$. The two-fold more potent pyrimidobenzothiazine $\mathbf{1 d}$ or isothiazolopyrimidine $\mathbf{2 d}$ was also converted under identical reductive conditions into the corresponding thiophenol derivative $\mathbf{4 d}$, which has similar anti-HIV activity to those of $\mathbf{1 d}$ and $\mathbf{2 d} .^{25}$ The thiophenol derivative $\mathbf{4 g}$, which was obtained by conversion from the inactive pyrimidobenzothiazine $\mathbf{1 g}$ or isothiazolopyrimidine $\mathbf{2 g}$ under the GSH-mediated conditions, exhibited no anti-HIV activity. Thus, the anti-HIV activities of the PD 404182 derivatives (1a, 1d and 19) and iso-
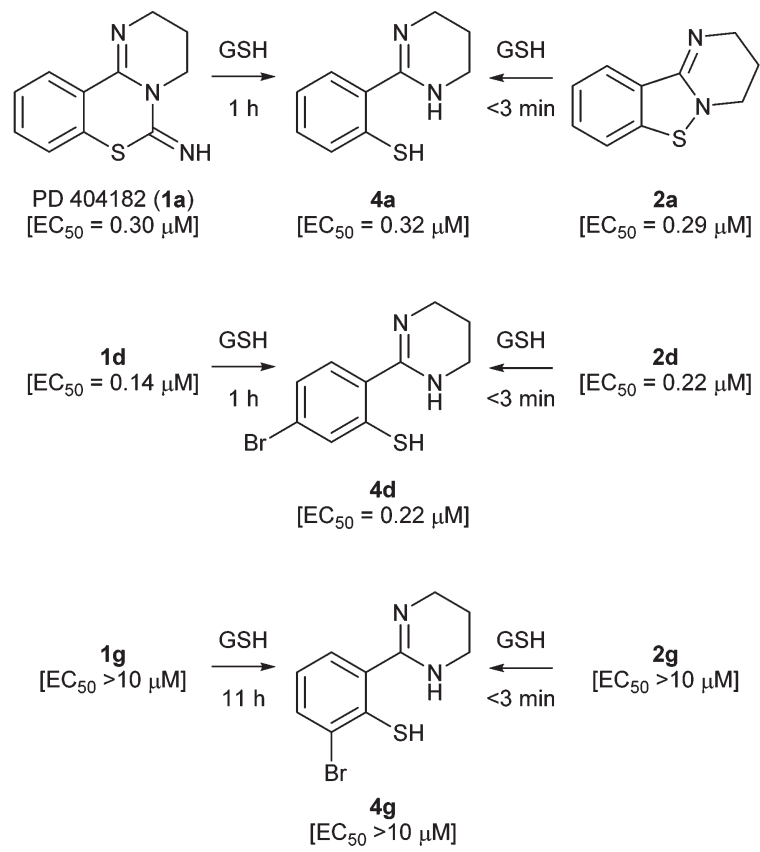

Fig. 4 Reactions of potent and inactive pyrimido[1,2-c][1,3]benzothiazin-6-imine and benzo[4,5]isothiazolo[2,3-a]pyrimidine derivatives under reductive conditions in the presence of $\mathrm{GSH}$ at $37^{\circ} \mathrm{C}$. $\mathrm{EC}_{50}$ values represent the concentration of the compound required to inhibit the HIV-1 infection by $50 \%$. The data were obtained from three independent experiments by the NCK assay.

thiazolopyrimidine derivatives (2a, $\mathbf{2 d}$ and $\mathbf{2 g}$ ) corresponded, at least in part, to those of the thiophenol derivatives (4a, $\mathbf{4 d}$ and $\mathbf{4 g}$ ). These results suggest that the tricyclic structures of $\mathbf{1 a}$ and $\mathbf{2} \mathbf{a}$ are the prodrug forms, which could be transformed into 4a under intracellular conditions of high GSH concentrations in host cells. Interestingly, inactive analogues with scaffolds similar to PD 404182 (1a) or compound 2a were not converted into thiophenol 4a (Fig. 5). For example, compound $10,{ }^{26}$ thioanisole derivative 7 , benzo[4,5]thiazolo[3,2-a]pyrimidine 11 (the structural isomer of $2 \mathbf{a}$ ), ${ }^{27}$ and saccharin-like derivative $12^{28}$ were completely stable under high concentrations of GSH for 24 hours. Therefore, the pyrimidobenzothiazine scaffold in $\mathbf{1 a}$ and the isothiazolopyrimidine scaffold in $\mathbf{2 a}$ structurally satisfied two criteria, which would make them good prodrugs of $\mathbf{4 a}$.

Taken together, the structure-activity relationships and antiviral profiles were similar between the PD 404182 derivatives 1 and benzo[4,5]isothiazolo[2,3- $a]$ pyrimidine derivatives 2. Under the reductive conditions corresponding to the intracellular environment, these scaffolds were efficiently converted to the common ring-opened thiophenol derivatives with potent anti-HIV activity. In addition, these two scaffolds inhibited not only HIV-1 infection at an early stage, but also several RNA and DNA viruses as we and others recently reported. ${ }^{5-8,10,11}$ In light of these findings, it was suggested that PD 404182 and benzo-[4,5]isothiazolo[2,3- $a]$ pyrimidine derivatives may achieve their antiviral activities by acting 


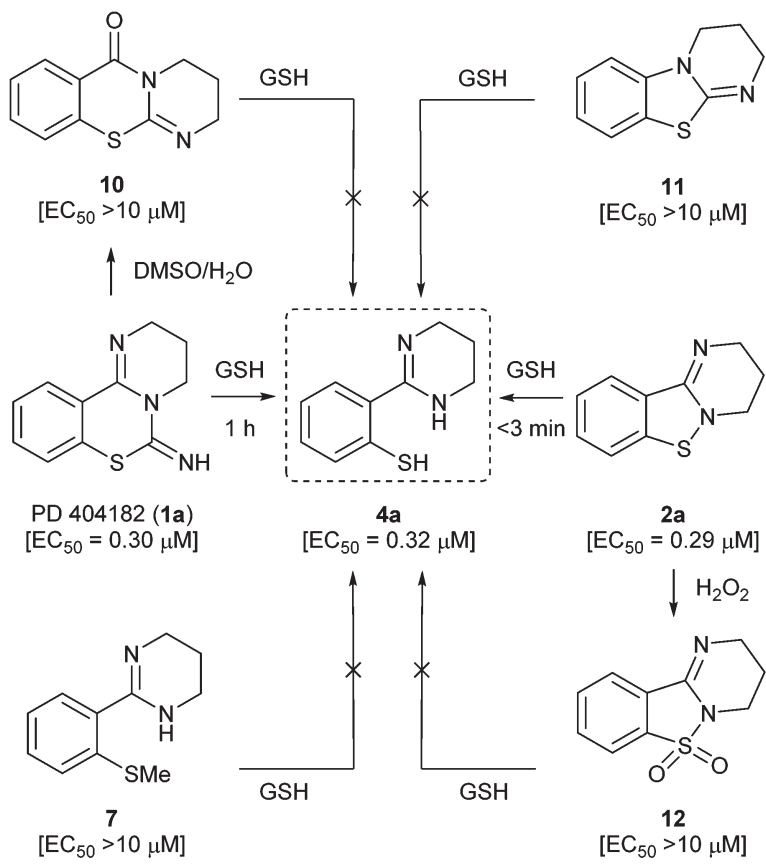

Fig. 5 Reactions of PD 404182, benzo[4,5]isothiazolo[2,3-a]pyrimidines and the inactive analogues under reductive conditions in the presence of $\mathrm{GSH}$ at $37^{\circ} \mathrm{C}$. $\mathrm{EC}_{50}$ values represent the concentration of the compound required to inhibit the HIV-1 infection by $50 \%$. The data were obtained from three independent experiments by the NCK assay.

through an identical intermediate or via an interaction with a similar target molecule(s) or mechanism of action in an intracellular compartment. A viral target molecule(s) or mechanism (s) has not yet been determined, ${ }^{14}$ but these heterocyclic compounds could conceivably regulate the defense mechanism(s) of the host cells.

\section{Conclusions}

We have unveiled the chemical transformations of pyrimido$[1,2-c][1,3]$ benzothiazin-6-imine and benzo[4,5]isothiazolo$[2,3-a]$ pyrimidine scaffolds, which yield compounds with potent antiviral activities. Under the reductive conditions meant to mimic intracellular GSH levels, the covalent $\mathrm{S}-\mathrm{N}$ bond of the isothiazole substructure in $2 \mathbf{a}$ was cleaved to provide the ring-opened 2-(2-mercaptophenyl)tetrahydropyrimidine $4 \mathbf{a}$ with potent anti-HIV activity, which was also generated from PD 404182 (1a) under identical conditions. The similar structure-activity relationships and antiviral profiles between compounds 1a and 2a suggested that these could possibly be the prodrug forms for the common bioactive substance $\mathbf{4 a}$ that binds with the potential target molecule(s) in host cells.

\section{Experimental section}

\section{General}

${ }^{1} \mathrm{H}$ NMR spectra were recorded using a JEOL ECA-500 spectrometer. Chemical shifts are reported in $\delta(\mathrm{ppm})$ relative to
$\mathrm{Me}_{4} \mathrm{Si}$ as an internal standard. ${ }^{13} \mathrm{C}$ NMR spectra were referenced to the residual solvent signal. Exact mass (HRMS) spectra were recorded on a JMS-HX/HX 110A mass spectrometer or Shimadzu LC-ESI-IT-TOF-MS equipment. For flash chromatography, Wakogel C-300E (Wako) and CHROMATOREX NH DM1080 (Fuji Silysia) were employed. For analytical HPLC, a Cosmosil 5C 18 -ARII column $(4.6 \times 250 \mathrm{~mm}$, Nacalai Tesque, Inc.) was employed with a linear gradient of $\mathrm{CH}_{3} \mathrm{CN}$ containing $0.1 \%(\mathrm{v} / \mathrm{v})$ aq. TFA at a flow rate of $1 \mathrm{~cm}^{3} \mathrm{~min}^{-1}$, and eluting products were detected by UV at $254 \mathrm{~nm}$. Preparative HPLC was performed using a Cosmosil $5 \mathrm{C}_{18}$-ARII preparative column $(20 \times 250 \mathrm{~mm}$, Nacalai Tesque, Inc. $)$ with a linear gradient of $\mathrm{CH}_{3} \mathrm{CN}$ containing $0.1 \%(\mathrm{v} / \mathrm{v})$ aq. TFA at a flow rate of $8 \mathrm{~cm}^{3}$ $\min ^{-1}$. The purity of the compounds was determined as no less than $95 \%$ by combustion analysis or HPLC analysis. Preparation of the compounds 1-3, 4d, 6, 8, 13-15 was already reported from our laboratory. ${ }^{7,8,11,15}$

2-(2-Mercaptophenyl)-1,4,5,6-tetrahydropyrimidine

(4a). Method A: TFA $\left(3.70 \mathrm{~cm}^{3}, 50.0 \mathrm{mmol}\right)$ was added to a suspension of PD 404182 (1a) $(1.09 \mathrm{~g}, 5.00 \mathrm{mmol})$ in $\mathrm{CHCl}_{3}\left(50.0 \mathrm{~cm}^{3}\right)$ and $\mathrm{EtOH}\left(75.0 \mathrm{~cm}^{3}\right)$ dropwise. After being stirred at room temperature for $1 \mathrm{~h}$, the mixture was quenched with $\mathrm{Et}_{3} \mathrm{~N}$ $\left(7.20 \mathrm{~cm}^{3}, 50.0 \mathrm{mmol}\right)$ at $0{ }^{\circ} \mathrm{C}$ and was concentrated. The crude product was purified by flash chromatography over $\mathrm{NH}$ silica gel with $\mathrm{CHCl}_{3}-\mathrm{MeOH}(10: 0$ to $9: 1)$ to give the title compound $\mathbf{4 a}$ as yellow crystals (999 $\mathrm{mg}$, quant.); $\mathrm{mp}$ 208-210 ${ }^{\circ} \mathrm{C}$ (from $n$-hexane- $\mathrm{CHCl}_{3}-\mathrm{MeOH}$ ); IR (neat) $\nu_{\max } /$ $\mathrm{cm}^{-1}$ : 3185-3092 (SH), $1590(\mathrm{C}=\mathrm{N}) ; \delta_{\mathrm{H}}\left(500 \mathrm{MHz}, \mathrm{CD}_{3} \mathrm{OD}\right)$ : 2.05-2.09 (2H, m, $\left.\mathrm{CH}_{2}\right), 3.55\left(4 \mathrm{H}, \mathrm{t}, J\right.$ 5.7, $\left.\mathrm{CH}_{2}\right), 6.87-6.91(1 \mathrm{H}$, $\mathrm{m}, \mathrm{Ar}), 7.06\left(1 \mathrm{H}, \mathrm{ddd}, J_{1}=J_{2} 8.0, J_{3} 1.7, \mathrm{Ar}\right), 7.28\left(1 \mathrm{H}, \mathrm{dd}, J_{1} 7.7\right.$, $\left.J_{2} 1.4, \mathrm{Ar}\right), 7.56\left(1 \mathrm{H}, \mathrm{dd}, J_{1} 8.0, J_{2} 1.1, \mathrm{Ar}\right) ; \delta_{\mathrm{C}}(125 \mathrm{MHz}, \mathrm{DMSO}-$ $\left.d_{6}\right): 18.1,38.1$ (2C), 118.7, 122.8, 126.7, 128.8, 137.8, 158.9, 159.8; HRMS (FAB): $m / z$ calcd for $\mathrm{C}_{10} \mathrm{H}_{13} \mathrm{~N}_{2} \mathrm{~S}[\mathrm{M}+\mathrm{H}]^{+}$ 193.0799; found: 193.0801 .

Method B: 3,4-dihydro-2 $H, 6 H$-pyrimido[1,2-c][1,3]benzothiazine-6-thione $3 \mathrm{a}^{15}(1.15 \mathrm{~g}, 4.90 \mathrm{mmol})$ was suspended in $0.1 \mathrm{~N}$ $\mathrm{NaOH}$ in $\mathrm{MeOH}-\mathrm{H}_{2} \mathrm{O}\left(9: 1,98.0 \mathrm{~cm}^{3}\right)$. After being stirred under reflux for $12 \mathrm{~h}$, the mixture was quenched with $1 \mathrm{~N} \mathrm{HCl}$ until $\mathrm{pH}$ was adjusted to 7. The whole mixture was extracted with $\mathrm{CHCl}_{3}-\mathrm{MeOH}(95: 5)$, and dried over $\mathrm{MgSO}_{4}$. After concentration, the resulting solid was recrystallized from $\mathrm{Et}_{2} \mathrm{O}-\mathrm{CHCl}_{3}-\mathrm{MeOH}$ to give the title compound $\mathbf{4 a}$ as an yellow solid (655 mg, 70\%): spectral data were in good agreement with those of the compound that was synthesized using $\operatorname{method} \mathrm{A}$.

2-(3-Bromo-2-mercaptophenyl)-1,4,5,6-tetrahydropyrimidine (4g). By using a procedure similar to that described for the preparation of the compound $\mathbf{4 a}$ from $\mathbf{1 a}$, compound $\mathbf{1 g}^{\mathbf{7}}$ ( $45.0 \mathrm{mg}, 0.152 \mathrm{mmol}$ ) was converted to the title compound $\mathbf{4 g}$ as a colorless solid (29.6 mg, 72\%); mp 260-262 ${ }^{\circ} \mathrm{C}$ (from $n$-hexane- $\mathrm{CHCl}_{3}-\mathrm{MeOH}$ ); IR (neat) $\nu_{\max } / \mathrm{cm}^{-1}$ : 2895-2795 $(\mathrm{SH}), 1626(\mathrm{C}=\mathrm{N}) ; \delta_{\mathrm{H}}\left(500 \mathrm{MHz}, \mathrm{DMSO}-d_{6}\right): 1.88-1.93(2 \mathrm{H}, \mathrm{m}$, $\left.\mathrm{CH}_{2}\right), 3.44\left(4 \mathrm{H}, \mathrm{t}, J\right.$ 5.7, $\left.\mathrm{CH}_{2}\right), 6.58\left(1 \mathrm{H}, \mathrm{dd}, J_{1}=J_{2} 7.7, \mathrm{Ar}\right)$, $7.29(1 \mathrm{H}, \mathrm{d}, J$ 8.0, Ar), $7.53(1 \mathrm{H}, \mathrm{d}, J$ 8.0, Ar), $10.85(2 \mathrm{H}, \mathrm{br}$ $\mathrm{s}) ; \quad \delta_{\mathrm{C}}\left(125 \mathrm{MHz}, \mathrm{DMSO}-d_{6}\right): 17.8,38.2 \quad(2 \mathrm{C}), \quad 117.5$, 126.2 , 128.1, 132.8, 133.4, 160.1, 160.7; anal. calcd for 
$\mathrm{C}_{10} \mathrm{H}_{11} \mathrm{BrN}_{2} \mathrm{~S}: \mathrm{C}, 44.29 ; \mathrm{H}, 4.09 ; \mathrm{N}, 10.33$. Found: $\mathrm{C}, 44.12 ; \mathrm{H}$, $4.08 ; \mathrm{N}, 10.31$.

2-[2-(Methylthio)phenyl]-1,4,5,6-tetrahydropyrimidine

2-(Methylthio)benzaldehyde 5 (90\% purity, $0.430 \mathrm{~cm}^{3}$, $3.00 \mathrm{mmol})$ was reacted with propylenediamine $\left(0.300 \mathrm{~cm}^{3}\right.$, $3.60 \mathrm{mmol}), \mathrm{K}_{2} \mathrm{CO}_{3}(1.24 \mathrm{~g}, 9.00 \mathrm{mmol})$ and $\mathrm{I}_{2}(952 \mathrm{mg}$, $3.75 \mathrm{mmol})$. The crude compound was purified by flash chromatography over $\mathrm{NH}$ silica with $\mathrm{CHCl}_{3}-\mathrm{MeOH}(10: 0$ to $10: 1$ ) followed by recrystallization from $n$-hexane- $\mathrm{CHCl}_{3}$ to give the title compound 7 as colorless crystals (294 mg, 48\%): mp 110-112 ${ }^{\circ} \mathrm{C}$; IR (neat) $\nu_{\max } / \mathrm{cm}^{-1}: 1621(\mathrm{C}=\mathrm{N}) ; \delta_{\mathrm{H}}$ $\left(500 \mathrm{MHz}, \mathrm{CDCl}_{3}\right): 1.82-1.87\left(2 \mathrm{H}, \mathrm{m}, \mathrm{CH}_{2}\right), 2.43\left(3 \mathrm{H}, \mathrm{s}, \mathrm{CH}_{3}\right)$, $3.45\left(4 \mathrm{H}, \mathrm{t}, J 5.7, \mathrm{CH}_{2}\right), 4.68(1 \mathrm{H}, \mathrm{br} \mathrm{s}, \mathrm{NH}), 7.12\left(1 \mathrm{H}, \mathrm{ddd}, J_{1}=\right.$ $J_{2}$ 7.4, $\left.J_{3} 1.1, \mathrm{Ar}\right), 7.20$ (1H, d, $J 6.9$, Ar), 7.29 (1H, ddd, $J_{1}=J_{2}$ $\left.7.6, J_{3} 1.5, \mathrm{Ar}\right), 7.36\left(\mathrm{dd}, J_{1} 7.4, J_{2} 1.7,1 \mathrm{H}, \mathrm{Ar}\right) ; \delta_{\mathrm{C}}(125 \mathrm{MHz}$, $\mathrm{CDCl}_{3}$ ): 16.0, 20.6, 42.1 (2C), 124.6, 125.5, 128.3, 129.1, 136.7, 137.0, 154.8; HRMS (ESI): $m / z$ calcd for $\mathrm{C}_{11} \mathrm{H}_{15} \mathrm{~N}_{2} \mathrm{~S}[\mathrm{M}+\mathrm{H}]^{+}$ 207.0956; found: 207.0954.

2-(2-Aminophenyl)-1,4,5,6-tetrahydropyrimidine

(9). A

mixture of 2 -[2- $N$-( $p$-toluenesulfonylamino $)$ phenyl]-1,4,5,6tetrahydropyrimidine $8^{7}$ (494 mg, $1.50 \mathrm{mmol}$ ) in conc. $\mathrm{H}_{2} \mathrm{SO}_{4}$ $\left(10.0 \mathrm{~cm}^{3}\right)$ was stirred at $100{ }^{\circ} \mathrm{C}$ for $30 \mathrm{~min}$, the mixture was cooled to $0{ }^{\circ} \mathrm{C}$, and then $\mathrm{pH}$ was adjusted to $12-14$ with $2 \mathrm{~N} \mathrm{NaOH}$. The whole mixture was extracted with $\mathrm{CHCl}_{3}$, and dried over $\mathrm{MgSO}_{4}$. After concentration, the resulting solid was recrystallized from $n$-hexane- $\mathrm{CHCl}_{3}$ to give the title compound 9 as colorless crystals (137 $\mathrm{mg}, 52 \%)$ : $\mathrm{mp}$ 83-85 ${ }^{\circ} \mathrm{C}$; IR (neat) $\nu_{\max } / \mathrm{cm}^{-1}: 2931\left(\mathrm{NH}_{2}\right), 2851\left(\mathrm{NH}_{2}\right)$, $1620(\mathrm{C}=\mathrm{N}) ; \delta_{\mathrm{H}}\left(500 \mathrm{MHz}, \mathrm{CDCl}_{3}\right): 1.81-1.86\left(2 \mathrm{H}, \mathrm{m}, \mathrm{CH}_{2}\right)$, $3.48\left(4 \mathrm{H}, \mathrm{t}, J 5.7, \mathrm{CH}_{2}\right), 4.71(1 \mathrm{H}$, br s, NH$), 5.72\left(2 \mathrm{H}, \mathrm{br} \mathrm{s}, \mathrm{NH}_{2}\right)$, 6.61-6.66 (2H, m, Ar), 7.07-7.10 (1H, m, Ar), 7.23-7.26 (1H, m, $\mathrm{Ar}) ; \delta_{\mathrm{C}}\left(125 \mathrm{MHz}, \mathrm{CDCl}_{3}\right): 20.7,42.0$ (2C), 116.56, 116.61, 119.3, 126.3, 129.9, 147.1, 155.1; anal. calcd for $\mathrm{C}_{10} \mathrm{H}_{14} \mathrm{~N}_{3}$ : C, 68.54; H, 7.48; N, 23.98. Found: C, 68.28; H, 7.57; N, 23.75.

3,4-Dihydro-2H,6H-benzo[e]pyrimido[2,1-b][1,3]thiazin-6one (10). PD 404182 (1a) (20.0 mg, $0.0920 \mathrm{mmol}$ ) in DMSO $\left(0.920 \mathrm{~cm}^{3}\right)$ was dissolved in $\mathrm{H}_{2} \mathrm{O}\left(92.0 \mathrm{~cm}^{3}\right)$. After being stirred at $37{ }^{\circ} \mathrm{C}$ for $26 \mathrm{~h}$, the mixture was purified by HPLC. The resulting solid was dissolved in EtOAc, and washed with sat. $\mathrm{NaHCO}_{3}$. The extract was dried over $\mathrm{MgSO}_{4}$, and concentrated to give the title compound $\mathbf{1 0}$ as colorless crystals (5.2 mg, 27\%); mp $132-134{ }^{\circ} \mathrm{C}$ (from toluene); IR (neat) $\nu_{\max } /$ $\mathrm{cm}^{-1}: 1662(\mathrm{C}=\mathrm{O}), 1608(\mathrm{C}=\mathrm{N}) ; \delta_{\mathrm{H}}\left(500 \mathrm{MHz}, \mathrm{CDCl}_{3}\right)$ : 1.98-2.03 (2H, m, $\left.\mathrm{CH}_{2}\right), 3.57\left(2 \mathrm{H}, \mathrm{t}, J 5.7, \mathrm{CH}_{2}\right), 4.02(2 \mathrm{H}, \mathrm{t}$, $J$ 6.0, $\left.\mathrm{CH}_{2}\right), 7.17$ (1H, d, J 8.0, Ar), 7.26-7.29 (1H, m, Ar), $7.47\left(1 \mathrm{H}, \mathrm{ddd}, J_{1}=J_{2} 7.7, J_{3} 1.6, \mathrm{Ar}\right), 8.24\left(1 \mathrm{H}, \mathrm{dd}, J_{1} 8.0, J_{2} 1.1, \mathrm{Ar}\right)$; $\delta_{\mathrm{C}}\left(125 \mathrm{MHz}, \mathrm{CDCl}_{3}\right): 21.1,42.3,46.1,122.7,124.0,126.0,131.0$, 133.2, 134.3, 147.0, 161.7; HRMS (FAB): $\mathrm{m} / \mathrm{z}$ calcd for $\mathrm{C}_{11} \mathrm{H}_{11} \mathrm{~N}_{2} \mathrm{OS}[\mathrm{M}+\mathrm{H}]^{+}$219.0592; found: 219.0584 . Spectral data were in good agreement with those previously reported. ${ }^{26}$

Crystal structure: $\mathrm{C}_{11} \mathrm{H}_{10} \mathrm{~N}_{2} \mathrm{OS}, M_{\mathrm{w}}: 218.27$, primitive monoclinic, $a=10.7456(6), b=10.9466(6), c=16.6473(7) \AA, \beta=$ 97.422(2) $)^{\circ} V=1941.78(17) \AA^{3}$, space group $P 2_{1} / n$ (no. 14), $Z=$ 8. The data were collected with a Rigaku R-AXIS RAPID diffractometer using graphite monochromated Mo-K $\alpha$ radiation at -93 K. 18534 Reflections were measured, 4420 unique
$\left(R_{\text {int }}=0.0220\right)$ which were used in all calculations. The final $\mathrm{w} R$ was 0.0796 . The substance was crystallized from toluene. The CCDC deposition number: 1037500.

3,4-Dihydro-2H-benzo[4,5] thiazolo[3,2-a]pyrimidine Following the reported procedure, ${ }^{27}$ 2-chloro-1,3-benzothiazole $\left(0.619 \mathrm{~cm}^{3}, 5.00 \mathrm{mmol}\right)$ was converted to the title compound 11, as a pale yellow solid (407 $\mathrm{mg}, 2$ steps $73 \%$ ), by the reaction with 3-amino-1-propanol $\left(0.381 \mathrm{~cm}^{3}, 5.00 \mathrm{mmol}\right)$. The product (80.8 $\mathrm{mg}$ ) was purified by HPLC to give the compound $\mathbf{1 1}$ as a colorless solid $\left(72.3 \mathrm{mg}\right.$, TFA salt): IR (neat) $\nu_{\max } / \mathrm{cm}^{-1}$ : 3274-3181 (OH), $1672(\mathrm{C}=\mathrm{O}), 1632(\mathrm{C}=\mathrm{N}) ; \delta_{\mathrm{H}}(500 \mathrm{MHz}$, $\left.\mathrm{CD}_{3} \mathrm{OD}\right): 2.31-2.36\left(2 \mathrm{H}, \mathrm{m}, \mathrm{CH}_{2}\right), 3.70\left(2 \mathrm{H}, \mathrm{t}, J 5.7, \mathrm{CH}_{2}\right), 4.27$ $\left(2 \mathrm{H}, \mathrm{t}, J\right.$ 6.0, $\left.\mathrm{CH}_{2}\right), 7.42-7.45$ (1H, m, Ar), 7.57-7.61 (2H, m, Ar), $7.84\left(1 \mathrm{H}, \mathrm{d}, J\right.$ 8.0, Ar); $\delta_{\mathrm{C}}\left(125 \mathrm{MHz}, \mathrm{CD}_{3} \mathrm{OD}\right): 19.2,41.3,44.0$, 113.5, 118.0 (q, $J$ 291.5), 123.1, 124.1, 126.7, 129.2, 140.0, 162.4 (q, $J$ 36.0), 166.0; HRMS (FAB): $\mathrm{m} / z$ calcd for $\mathrm{C}_{10} \mathrm{H}_{11} \mathrm{~N}_{2} \mathrm{~S}$ $[\mathrm{M}+\mathrm{H}]^{+}$191.0643; found: 191.0641 .

3,4-Dihydro-2H-benzo[4,5]isothiazolo[2,3-a]pyrimidine $\mathbf{6 , 6}$ dioxide (12). $50 \% \mathrm{H}_{2} \mathrm{O}_{2}\left(0.0391 \mathrm{~cm}^{3}, 0.638 \mathrm{mmol}\right)$ was added to a suspension of compound $2 \mathrm{a}(48.5 \mathrm{mg}, 0.159 \mathrm{mmol}$, TFA salt) in TFA $\left(0.610 \mathrm{~cm}^{3}\right)$ dropwise. After being stirred at room temperature for $24 \mathrm{~h}$, the mixture was quenched with $\mathrm{Et}_{3} \mathrm{~N}$ $\left(1.50 \mathrm{~cm}^{3}\right)$, and the whole mixture was extracted with EtOAc. The extract was washed with sat. $\mathrm{NaHCO}_{3}$, brine, and dried over $\mathrm{MgSO}_{4}$. After concentration, the residue was purified by flash chromatography over aluminum oxide with $n$-hexaneEtOAc ( $3: 2$ to $1: 1)$ to give the title compound 12 as colorless crystals (25.2 mg, 71\%): mp 146-148 ${ }^{\circ} \mathrm{C}$ (from $\mathrm{Et}_{2} \mathrm{O}-\mathrm{MeOH}$ ); IR (neat) $\nu_{\max } / \mathrm{cm}^{-1}: 1670(\mathrm{C}=\mathrm{N}) ; \delta_{\mathrm{H}}\left(500 \mathrm{MHz}, \mathrm{CDCl}_{3}\right)$ : 2.01-2.05 (2H, m, $\left.\mathrm{CH}_{2}\right), 3.70\left(2 \mathrm{H}, \mathrm{t}, J 5.7, \mathrm{CH}_{2}\right), 3.79(2 \mathrm{H}, \mathrm{t}$, J 6.0, $\left.\mathrm{CH}_{2}\right), 7.70-7.76(2 \mathrm{H}, \mathrm{m}, \mathrm{Ar}), 7.85-7.88(1 \mathrm{H}, \mathrm{m}, \mathrm{Ar})$, 7.98-8.01 (1H, m, Ar); $\delta_{\mathrm{C}}\left(125 \mathrm{MHz}, \mathrm{CDCl}_{3}\right): 19.5,36.5,44.2$, $120.7,122.8,129.6,132.4,133.6,134.8,142.7$; anal. calcd for $\mathrm{C}_{10} \mathrm{H}_{10} \mathrm{~N}_{2} \mathrm{O}_{2} \mathrm{~S}: \mathrm{C}, 54.04 ; \mathrm{H}, 4.54 ; \mathrm{N}, 12.60$. Found: C, 53.89; $\mathrm{H}$, $4.74 ; \mathrm{N}, 12.36$.

2-(2-Hydroxyphenyl)-1,4,5,6-tetrahydropyrimidine $\quad(16) .{ }^{21} \mathrm{~A}$ mixture of methyl salicylate $\left(1.29 \mathrm{~cm}^{3}, 10.0 \mathrm{mmol}\right)$ and propylenediamine $\left(2.56 \mathrm{~cm}^{3}, 30.0 \mathrm{mmol}\right)$ was refluxed for $16 \mathrm{~h}$. The crude product was dissolved in $\mathrm{MeOH}$, and crystallized with $\mathrm{Et}_{2} \mathrm{O}$. The precipitate was filtered, and the unreacted propylenediamine was removed by washing with $\mathrm{Et}_{2} \mathrm{O}$. The resulting solid was purified by flash chromatography over aluminum oxide with $\mathrm{CHCl}_{3}-\mathrm{MeOH}(10: 0$ to $10: 1)$ to give the title compound 16 as colorless crystals (497 mg, 28\%): mp 259-261 ${ }^{\circ} \mathrm{C}$ (from $\left.\mathrm{Et}_{2} \mathrm{O}-\mathrm{MeOH}\right) ; \mathrm{IR}$ (neat) $\nu_{\max } / \mathrm{cm}^{-1}: 3212-3050(\mathrm{OH}), 1620$ $(\mathrm{C}=\mathrm{N}) ; \delta_{\mathrm{H}}\left(500 \mathrm{MHz}, \mathrm{DMSO}-d_{6}\right): 1.83-1.88\left(2 \mathrm{H}, \mathrm{m}, \mathrm{CH}_{2}\right), 3.40$ $\left(4 \mathrm{H}, \mathrm{t}, J\right.$ 5.7, $\left.\mathrm{CH}_{2}\right), 6.27-6.30(1 \mathrm{H}, \mathrm{m}, \mathrm{Ar}), 6.46(1 \mathrm{H}, \mathrm{d}, J$ 8.6, Ar), 7.04-7.08 (1H, m, Ar), 7.45 (1H, dd, $J_{1} 8.0, J_{2}$ 1.7, Ar), 12.10 $\left(1 \mathrm{H}\right.$, br s, OH); $\delta_{\mathrm{C}}\left(125 \mathrm{MHz}, \mathrm{CD}_{3} \mathrm{OD}\right): 20.0,39.3$ (2C), 111.2, $114.5,124.4,126.3,135.1,160.9,172.5$; anal. calcd for $\mathrm{C}_{10} \mathrm{H}_{12} \mathrm{~N}_{2} \mathrm{O}: \mathrm{C}, 68.16 ; \mathrm{H}, 6.86 ; \mathrm{N}, 15.90$. Found: C, 68.13; H, $7.03 ; \mathrm{N}, 16.09$.

\section{Determination of anti-HIV activity}

The anti-HIV activity of a series of compounds against HIV-1 $1_{\text {IIIB }}$ was determined by the NCK assay. ${ }^{29}$ The target 
cells (NCK45- $\beta$-Gal; $10^{4}$ cells per well) were plated in 96-well flat microtiter culture plates. On the following day, the cells were inoculated with HIV-1 (60 NCK U per well, giving 60 blue cells after $48 \mathrm{~h}$ of incubation) and cultured in the presence of various concentrations of the test compounds in fresh medium. Forty-eight hours after viral exposure, all the blue cells stained with X-Gal (5-bromo4-chloro-3-indolyl- $\beta$-D-galactopyranoside) were counted in each well. Cytotoxic effects were not observed at $10 \mu \mathrm{M}$ except for compound $2 \mathrm{~g}$.

The activity of test compounds was determined as the concentration that blocked HIV-1 infection by $50 \%$ (50\% effective concentration $\left.\left[\mathrm{EC}_{50}\right]\right)$. $\mathrm{EC}_{50}$ was determined by using the following formula:

$$
\mathrm{EC}_{50}=10^{[\log (A / B) \times(50-C) /(D-C)+\log (B)]},
$$

where $A$, of the two points on the graph that bracket $50 \%$ inhibition, the higher concentration of the test compound; $B$, of the two points on the graph that bracket $50 \%$ inhibition, the lower concentration of the test compound; $C$, inhibitory activity (\%) at the concentration $B ; D$, inhibitory activity (\%) at the concentration $A$.

\section{Glutathione-mediated transformation of pyrimidobenzothiazine and isothiazolopyrimidine derivatives}

The compound ( $1 \mathrm{mM}$ ) was incubated in $10 \mathrm{mM}$ GSH (in a mixture of $50 \mathrm{mM}$ phosphate buffer ( $\mathrm{pH}$ 7.4) and MeCN $[75: 25(\mathrm{v} / \mathrm{v})$ or $1: 1(\mathrm{v} / \mathrm{v})])$ at $37^{\circ} \mathrm{C}$. The sample was analyzed by HPLC and the peak area was recorded by UV detection at $254 \mathrm{~nm}$. The concentrations of the products were calculated using previously determined calibration curves. Of note, the GSH-mediated transformation from 1a was slightly accelerated by the addition of MeCN in phosphate buffer.

\section{Acknowledgements}

This work was supported by Grants-in-Aid for Scientific Research from JSPS, Japan; Platform for Drug Discovery, Informatics, and Structural Life Science from MEXT, Japan; a Grantin-Aid for Research on HIV/AIDS from the Ministry of Health and Welfare of Japan. T.M. is grateful for JSPS Research Fellowships for Young Scientists.

\section{References}

1 PD 404182 (1a) was previously reported to be an enzyme inhibitor against 3-deoxy-D-manno-octulosonic acid 8-phosphate synthase $\mathrm{e}^{2}$ and phosphopantetheinyl transferase. ${ }^{3}$ In addition, it was recently reported that PD 404182 (1a) inhibits human dimethylarginine dimethylaminohydrolase isoform 1 (DDAH). ${ }^{4}$

2 M. R. Birck, T. P. Holler and R. W. Woodard, J. Am. Chem. Soc., 2000, 122, 9334-9335.
3 C. R. Vickery, N. M. Kosa, E. P. Casavant, S. Duan, J. P. Noel and M. D. Burkart, ACS Chem. Biol., 2014, 9, 1939-1944.

4 Y. T. Ghebremariam, D. A. Erlanson and J. P. Cooke, J. Pharmacol. Exp. Ther., 2014, 348, 69-76.

5 K. Chockalingam, R. L. Simeon, C. M. Rice and Z. Chen, Proc. Natl. Acad. Sci. U. S. A., 2010, 107, 3764-3769.

6 A. M. Chamoun, K. Chockalingam, M. Bobardt, R. Simeon, J. Chang, P. Gallay and Z. Chen, Antimicrob. Agents Chemother., 2012, 56, 672-681.

7 T. Mizuhara, S. Oishi, H. Ohno, K. Shimura, M. Matsuoka and N. Fujii, Org. Biomol. Chem., 2012, 10, 6792-6802.

8 T. Mizuhara, S. Oishi, H. Ohno, K. Shimura, M. Matsuoka and N. Fujii, Bioorg. Med. Chem., 2012, 20, 64346441.

9 T. Mizuhara, S. Oishi, H. Ohno, K. Shimura, M. Matsuoka and N. Fujii, Bioorg. Med. Chem., 2013, 21, 2079-2087.

10 A. M. Chamoun-Emanuelli, M. Bobardt, B. Moncla, M. K. Mankowski, R. G. Ptak, P. Gallay and Z. Chen, Antimicrob. Agents Chemother., 2014, 58, 687-697.

11 S. Okazaki, T. Mizuhara, K. Shimura, H. Murayama, H. Ohno, S. Oishi, M. Matsuoka and N. Fujii, Bioorg. Med. Chem., 2015, 23, 1447-1452.

12 M. Baba, D. Schols, R. Pauwels, H. Nakashima and E. De Clercq, J. Acquired Immune Defic. Syndr., 1990, 3, 493-499.

13 T. Matthews, M. Salgo, M. Greenberg, J. Chung, R. DeMasi and D. Bolognesi, Nat. Rev. Drug Discovery, 2004, 3, 215225.

14 Of note, it was reported that PD 404182 showed the antiviral activities by the virucidal effect via the physical disruption of virions, see ref. 6 and 10 .

15 T. Mizuhara, S. Oishi, N. Fujii and H. Ohno, J. Org. Chem., 2010, 75, 265-268.

16 M. Ishihara and H. Togo, Tetrahedron, 2007, 63, 14741480.

17 For a review on the function of glutathione, see: R. Franco, O. J. Schoneveld, A. Pappa and M. I. Panayiotidis, Arch. Physiol. Biochem., 2007, 113, 234-258 and references cited therein.

18 Compound 4a was also identified from HTS as an antibacterial agent that inhibits localization of lipoproteins (Lol) during cell wall biosynthesis, see: H. Ito, A. Ura, Y. Oyamada, H. Yoshida, J. Yamagishi, S. Narita, S. Matsuyama and H. Tokuda, Microbiol. Immunol., 2007, 51, 263-270.

19 During the course of our investigations, an initial report describing GSH-mediated degradation of PD 404182 appeared, see ref. 4 .

20 In the absence of GSH, compound 1a was converted into pyrimidothiazinone $\mathbf{1 0}$ as discussed above.

21 R. Mitsuhashi, T. Suzuki and Y. Sunatsuki, Inorg. Chem., 2013, 52, 10183-10190.

22 J. A. Loo, T. P. Holler, J. Sanchez, R. Gogliotti, L. Maloney and M. D. Reily, J. Med. Chem., 1996, 39, 4313-4320.

23 T. Vercruysse, B. Basta, W. Dehaen, N. Humbert, J. Balzarini, F. Debaene, S. Sanglier-Cianférani, 
C. Pannecouque, Y. Mély and D. Daelemans, Retrovirology, 2012, 9, 95-108.

24 C. Pannecouque, B. Szafarowicz, N. Volkova, V. Bakulev, W. Dehaen, Y. Mély and D. Daelemans, Antimicrob. Agents Chemother., 2010, 54, 1461-1468.

25 The transformations from $\mathbf{1 f}$ and $\mathbf{2 f}$ into the ring-opened thiophenol derivative were also observed in the presence of GSH.
26 D. Chen, J. Wu, J. Yang, L. Huang, Y. Xiang and W. Bao, Tetrahedron Lett., 2012, 53, 7104-7107.

27 P. A. Woods, L. C. Morrill, T. Lebl, A. M. Z. Slawin, R. A. Bragg and A. D. Smith, Org. Lett., 2010, 12, 2660-2663.

28 S. Sivaramakrishnan, A. H. Cummings and K. S. Gates, Bioorg. Med. Chem. Lett., 2010, 20, 444-447.

29 K. Kajiwara, E. Kodama, Y. Sakagami, T. Naito and M. Matsuoka, J. Clin. Microbiol., 2008, 46, 792-795. 